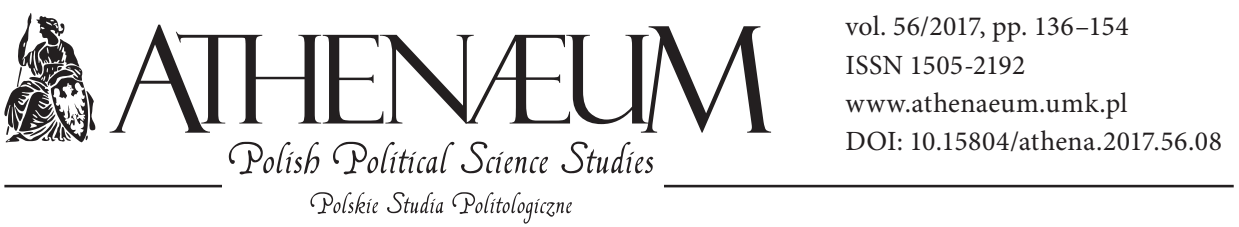

\title{
INEQUALITY: DORMANT THREAT TO STABILITY IN THE BRICS*
}

\author{
NIERÓWNOŚĆ: UŚPIONE ZAGROŻENIE \\ DLA STABILNOŚCI W BRICS
}

Marek Rewizorski**

\begin{abstract}
Being perceived by the West as a powerful yet heterogeneous "deconstructing power" and an external threat to western supremacy in global governance, the BRICS members are facing a serious "dormant threat" coming from within - economic inequalities. By asking whether inequality, like "bad cholesterol", may silently kill the sustainability of growth by restraining access to education, health or knowledge, this article provides an assessment of the relation between the increasing inequality and rising political instability in BRICS countries. The first section of this article investigates various approaches to income and wealth inequalities, and provides a literature overview. The second section accentuates the deconstructing features of inequality in BRICS countries, which are encapsulated as the " $3 \mathrm{Ws}$ ": weak markets, weak governments, and weak institutions. The third section looks into the inequality dynamics in BRICS members
\end{abstract}

\section{ABSTRAKT}

Postrzegani przez Zachód jako potężna a jednocześnie heterogeniczna „potęga dekonstrukcyjna” i zewnętrzne zagrożenie dla zachodniej supremacji w globalnym zarządzaniu, uczestnicy BRICS stoją w obliczu poważnego wewnętrznego „uśpionego zagrożenia” - nierówności ekonomicznych. Pytając, czy nierówność, podobnie jak „zły cholesterol”, może po cichu „zabić” trwałość wzrostu poprzez ograniczenie dostępu do edukacji, zdrowia lub wiedzy, zanalizowano związek między rosnącymi nierównościami a wzrastającą niestabilnością polityczną w państwach BRICS. W pierwszej części artykułu prześledzono różne podejścia do nierówności dochodowych oraz dokonano przeglądu literatury. W drugiej części zaakcentowano dekonstrukcyjne cechy nierówności w państwach BRICS, które ujęto w formule „3S”: słabe rynki, słabe rządy i słabe instytucje. W trzeciej części zanalizowano dynamikę nierówności wśród członków BRICS, dowodząc,

* This article is part of the "Global Economic Governance - Actors, Areas of Influence, Interactions" research project (OPUS, UMO-2016/23/B/HS5/00118) funded by the National Science Centre, Poland.

** University of Gdańsk, Faculty of Social Science. 
showcasing that the huge income disparities in BRICS (GINI > 0.40), combined with high food and house prices, not only fuel opportunity inequalities and growing social anger, but also lead to political instability and setbacks on the path to balanced growth. The final part presents the main conclusions.

Keywords: BRICS, economic inequalities, political stability, institutions, growth że ogromne dysproporcje w dochodach BRICS (GINI > 0,40), w połączeniu z wysokimi cenami żywności i mieszkań, nie tylko powodują nierówności w zakresie możliwości awansu społecznego i napędzają gniew społeczny, ale także prowadzą do niestabilności politycznej i stanowią przeszkody na drodze do zrównoważonego wzrostu. W końcowej części przedstawiono wnioski i uogólnienia.

Słowa kluczowe: BRICS, nierówności ekonomiczne, stabilność polityczna, instytucje, wzrost

In international debates the establishment of the BRICS group is often perceived as "one of the most significant geopolitical events of the new century" (Lukov, 2012). Taking into account the growing economic power of its members, demography, natural resources, combined gross domestic product (GDP), participation in the leading international organisations and structures, common principles (openness, pragmatism, solidarity, mutual assistance, inclusiveness), and common strategic interests, the BRICS states strive "to extend their participation in key institutions of global governance" (Held, 2010). At the same time their positions in the international political order are far from convergent. Oliver Stunkel noted that while Brazil and India are pushing for a more fundamental redistribution of institutional power in today's global governance structures, Russia and China - both permanent members of the UN Security Council - are essentially status quo powers, reluctant to change a system that has served them well during the past decades. In his view, "the BRICS are troubled by internal rivalries and contradictions that have stymied the group's ability to take any significant action toward a primary goal: reforming Western-dominated international financial institutions" (Stunkel, 2015). Despite the stark differences arising from their divergent interests, values, political systems and objectives, even their critics admit the increasing institutionalisation of the group. Its members more and more frequently, albeit not always fruitfully, attempt to coordinate positions, and thus constitute a block of states speaking with one voice. Rejecting the "western" vision of the global order, denying the neo-liberal nature of global governance and aiming at its transformation, they are becoming a heterogenic group of powers capable of occasionally uniting in their resistance against the 
"G7 world". Coming into sight as players with a significant amount of political clout, as exemplified by their united stance during the meeting in March 2014 on the sidelines of the Nuclear Security Summit in The Hague, where the grouping's foreign ministers opposed restrictions on the participation of Russian President Vladimir Putin at the G20 Summit in Australia in November 2014, they showed their ability to cast a veto against the univocal attempt to isolate Russia and rebuild "the G20 cathedral", according to purely western origins.

Being perceived by the West as a powerful yet heterogeneous "deconstructing power" and an external threat to western supremacy in global governance, the BRICS members are facing a serious "dormant threat" coming from within economic inequalities. By asking whether inequality, like "bad cholesterol", may silently kill the sustainability of growth by restraining access to education, health or knowledge, this article provides an assessment of the relation between the increasing inequality and rising political instability in BRICS countries. The first section of this article investigates various approaches to income and wealth inequalities, and provides a literature overview. The second section accentuates the deconstructing features of inequality in BRICS countries, which are encapsulated as the " $3 \mathrm{Ws":} \mathrm{weak} \mathrm{markets,} \mathrm{weak} \mathrm{governments,} \mathrm{and} \mathrm{weak} \mathrm{institutions.} \mathrm{The}$ third section looks into the inequality dynamics in BRICS members showcasing that the huge income disparities in BRICS (GINI > 0.40), combined with high food and house prices, not only fuel opportunity inequalities and growing social anger, but also lead to political instability and setbacks on the path to balanced growth. The final part presents the main conclusions.

\section{INEQUALITY, GROWTH AND POLITICAL STABILITY - THEORETICAL FRAMEWORK}

Inequality has not been amongst the hotly debated issues for a long time. Since global capitalism's universal overcoming of Marx's assumption that inequality will inevitably push workers towards overthrowing the power of capital owners, only scant analyses dared to focus on how inequality might put developing states in a vulnerable position, undermining the status quo, sparking urban riots and mass demonstrations, thus hurting emerging economies and, ultimately, catalysing far-reaching social and political reforms. The US economist Kenneth Rogoff, in the Portuguese business newspaper Jornal de Negócios, noted that" [i] nequality is the big wild card in the next decade of global growth, and not just 
in North Africa” (Rogoff, 2011). As he puts it, "[n] ot just corruption and political repression [leads to tensions and instability - M.R.]. High unemployment, glaring inequality, and soaring prices for basic commodities are also a huge factor [...]. Within countries, inequality of income, wealth, and opportunity is arguably greater than at any time in the last century. Yet, with inequality reaching levels similar to 100 years ago, the status quo has to be vulnerable. Instability can express itself anywhere" (Rogoff, 2011). Similar comments on the scale of inequality were made by Thomas Piketty (2014). The French economist, in his opus magnum Capital in the Twenty-First Century, noted that since the 1970s, income inequality has increased significantly in the rich countries, especially the United States, where the concentration of income in the first decade of the twenty-first century slightly exceeded the level attained in the second decade of the previous century. However, he optimistically assumed that "the very rapid growth of poor and emerging countries, especially China, may well prove to be a potent force for reducing inequalities at the global level, just as the growth of the rich countries did during the period 1945-1975" (Piketty, 2014). In earlier studies, which the French scholar conducted with a number of prominent economists (Piketty, Saez, 2003; Atkinson, Piketty, Saez, 2011), inequality over the entire twentieth century was explained, and empirical evidence produced, undermining Kuznets' hypothesis according to which inequality everywhere can be expected to follow a "bell curve" (it should first increase and then decrease over the course of industrialisation and economic development; Kuznets, 1955). Piketty showed that, after a downward swing, inequality in Western states sharply increased in the last quarter of the century (Milanovic, 2010).

Asking what effect economic inequality exerts on growth, economists (and more rarely, political scientists) are divided into several camps. To measure the above-mentioned disparity they use an extensive set of economic indicators, such as: (1) purchasing power; (2) inflation-adjusted gross domestic product per capita; (3) Theil Index; (4) Atkinson Index; (5) the Gini coefficient; (6) educational indicators, such as the age-specific number of years of education attained; (7) environmental indicators, such as the use of improved sources of drinking water and sanitation facilities; (8) demographic variables, such as: the size of rural and total populations, and life expectancy; (9) health indicators, such as infant, child and maternal mortality rates. The most commonly used is the so-called "Gini coefficient" (or Gini Index), which has become by far the most popular measure for inequality since it was first introduced by the Italian 
statistician Corrado Gini (1884-1965) almost a century ago (Luebker, 2010). It can theoretically take any value between zero (perfect equality, i.e., everybody has the same income) and one (total inequality, i.e., all income goes to a single person). However, in some cases the Gini coefficient is multiplied by 100 , and then ranges between 0 and 100 .

A number of scholars suggest that a high Gini coefficient is a negative contributor to growth (Alesina, Rodrik, 1994). Additionally, numerous studies indicate a close relationship between high income inequalities (GINI ca. $>0.40$ and higher) and rising political instability (Alesina, Perotti, 1996). According to them, income inequality leads to social discontent and fuels social unrest. The latter, by increasing the probability of coups, revolutions, mass violence, generating policy uncertainty and threatening property rights, has a negative effect on investment and, as a consequence, reduces growth (Alesina, Perotti, 1996). In various studies Persson and Tabellini (1994), Bertola (1993), and Perotti (1993) highlighted the link between the exacerbating of equality and a mounting demand for fiscal redistribution which, if financed by distortionary taxation, acts as factor impeding growth rates. In a widely quoted paper Alesina and Perotti (1996) tested 72 countries for the period 1960-85 measuring socio-political instability with indices which capture the occurrence of more or less violent phenomena of political unrest. Having asked the questions of: (1) does income inequality increase political instability?, and (2) does political instability reduce investment?, they gave positive answers to both questions. More specifically, Alesina and Perotti noticed that "political stability is enhanced by the presence of a wealthy middle class [...] political instability has an adverse effect on investment and, therefore, on growth" (Alesina, Perotti, 1996).

A contrasting view on the link between inequality and growth was expressed by Kaldor and Kalecki, who independently came to the conclusion that significant income inequalities have a positive effect on growth (Kaldor, 1960; Kalecki, 1971). They based their arguments on models with fixed savings rates in which workers were assumed to have a zero savings rate. According to the model, a transfer of resources from workers to capitalists would raise the economy's aggregate savings rate and therefore the growth rate (Rodríguez, 2000). To put it simply, the "Kaldorian" pro-inequality model held that more inequality favours more accumulation, because the rich save more than the poor. This view was supported by Hongyi Li and Heng-fu Zou (1998) who showed that more inequality can produce higher growth. However, Barro and Sala-i-Martin (1995) found a non-linear relationship: inequality appears to be 
good for growth at high levels of income but bad for growth at low levels of income. It is noteworthy that in BRICS countries, where a small proportion of super-rich people amass a significant portion of the national wealth, the negative impact of inequality on growth can be especially pronounced. Massive social inequalities in emerging economies may be exemplified by data summarised in the Global Wealth Report (2013), published annually by Crédit Suisse. According to the 2013 report, 5.6 per cent of the Russian population possesses between $\$ 10,000$ and $\$ 100,000,0.6$ per cent between $\$ 100,000$ and $\$ 1$ million, while 0.1 per cent has more than $\$ 1$ million. The bank indicated that Russia has the highest level of wealth inequality in the world, apart from small Caribbean nations with resident billionaires. In 2013, 110 Russian billionaires (0.00008 per cent of the population) owned 35 per cent of all wealth, while 94 per cent of the adult population, estimated at 143 million, owned less than $\$ 10,000$ (Global Wealth Report, 2013).

The third approach to the inequality and growth debate focuses on the distinction between positive and negative inequality. In asking how inequality affects economic efficiency, Branco Milanovic compares inequality to "good" and "bad" cholesterol. "Good inequality", he writes, is "needed to create incentives for people to study, work hard, or start risky entrepreneurial projects" (Milanovic, 2010). "Bad inequality" on the contrary "discourages from individual efforts, provokes discouragement, bad habits and provides means to preserve acquired positions rather than motivate to excel" (ibid.). François Facchini (2008) puts forward similar arguments. Not only does he refer to the distinction between "good" and "bad" inequalities, but based on Baumol's production-predation model (Baumol, 1990), according to which good inequalities would be the result of productive entrepreneurial activity, while bad inequalities would be the consequences of their unproductive activity, Facchini argues that "the positive or negative relationship between inequalities and growth in production depends upon the way individuals are enriched" (Facchini, 2008). If they are enriched by the discovery of a market profit, this has a positive effect on growth and economic progress. If they are enriched by the discovery of a rent, that, on the other hand, has a negative effect on growth. 


\section{INEQUALITY AND THE "3WS": WEAK MARKETS, WEAK GOVERNMENTS, WEAK INSTITUTIONS}

Shifting the debate about the distinction between "good" and "bad" inequality to BRICS, and - more generally - to developing countries, it is worth recalling Nancy Birdsall's assumption about "constructive" and "destructive" inequality. In a press article published in 2007, this renowned economist noted: "[d]istinguishing between constructive and destructive inequality is useful. To clarify the distinction: inequality is constructive when it creates positive incentives at the micro level. Such inequality reflects differences in individuals' responses to equal opportunities and is consistent with efficient allocation of resources in an economy. In contrast, destructive inequality reflects privileges for the already rich and blocks potential for productive contributions of the less rich" (Birdsall, 2007). Against conventional textbook economic approaches, describing a tradeoff between growth and equality, where rising inequality (also in countries like China, Russia or Brazil) contributes to boosting economic growth and the enrichment of entrepreneurial individuals who get high returns from their risk-propelled investments, Birdsall lauds the role of tax-financed redistribution programmes in developing countries, which neo-liberals have always considered as bad, undermining individual responsibility and the work ethic, and thus making them responsible for sluggish growth. She accentuates the deconstructing features of inequality in the developing world, no matter if the debate is on East Asia, Latin America, or Africa (e.g., South Africa's GINI coefficient in 2011-63.4 - was among the highest in the world). They can be encapsulated as the " $3 \mathrm{Ws":}$ weak markets, weak governments, and weak institutions.

Weak markets and weak governments in developing countries translate into less effective compensation for market failure. Moreover, governmental institutions are less coherent in their activities, which adversely affects the accountability of the select few who are in power. The example of Brazil, which in the second half of 2015 was severely hit by rising inflation (standing at approx. 9.53 per cent in August), weak GDP growth (-2.6 per cent), a large fiscal deficit ( 9 per cent of the GDP) and high public debt (72.6 per cent), shows the structural weaknesses of an economy once hailed as a star performer in the emerging world (Garcia-Herrero, 2015). With the Dutch disease of de-industrialisation and falling productivity, combined with unit labour costs more than doubling from 2001 to 2011 and poor infrastructure described in the Economist special report as a "road to hell" (The Economist, 2013a), the market renders it difficult for the 
government to provide public services for citizens in the education or health sectors, not to mention rising housing inequality. In Brazil, where in 2010 about 14.6 million people were illiterate (MercoPress, 2011), despite a downward trend, illiteracy rates are still among the highest in Latin America. The government still fails to find a solution to this problem, particularly in the poor north-east, where the rate is almost double the Brazilian average, standing at 17 per cent, and a lot higher than the south and south-east rates which do not exceed 4.7 per cent. The worst state is Alagoas in the north-east, where 22.52 per cent of the population remained illiterate over a ten-year period. With nearly 90 per cent of illiterate people aged 25 and over, and almost 70 per cent of all illiterates being found in the rural population (Couto Soares, Scerri, Maharajh, 2014), Brazilian investment in human capital in the long-term perspective needs to be huge. However, despite the dropping illiteracy rate from 13.6 per cent in 2000 to 9.6 per cent in 2010, the objective is merely "wishful thinking" with a sluggish economy, decelerated additionally by a downturn in Brazilian commodity exports (soybeans, crude oil and iron ore) to China and the depreciation of the Brazilian real against the dollar, implying that Brazilian companies will have to pay more for their dollar-denominated debt.

The weak institutions dilemma refers to the fragility of behavioural systems and relations that regulate the life and activity of individuals (Mihăilescu, 1974). Where social institutions are fragile, inequality discourages the civic and social life that underpins the collective decision-making necessary for healthy, functioning societies. Being, in fact, an asset of social capital, social institutions enhance civic engagement and levels of mutual trust among community members. There is some evidence to suggest that poverty (incidental to economic inequality) is linked to depletion of social capital (Wilson, 1991) and that a lower level of social trust is associated with higher rates of many major causes of death, including coronary heart disease, malignant neoplasms, cerebrovascular disease, accidental injury, and infant mortality (Kawachi, Kennedy, Lochner, Prothrow-Stith, 1997). Refocusing from the behavioural to the political environment, a correlation between a high rate of inequality (typical for all BRICS members) and a low rate of social capital has been affirmed by Vladimir Shlapentokh, who - surveying the attitudes of Russians towards their social institutions - noted that Russians mistrust state social institutions and political institutions in particular. There is not one institution that can garner more than 40 to 50 per cent of the nation's trust. According to Shlapentokh, in terms of their lack of confidence in social institutions, the Russians are behind not only the most advanced countries in 
the world, but even countries known for their unstable political systems, such as Colombia or Nigeria (Shlapentokh, 2006). With rising inflation, weak GDP growth, a tense political situation emanating from corruption scandals and the inefficiency of state-owned enterprises (SOEs), which has delayed the action needed for economic recovery, it is no wonder that Russia - a significant member of the BRICS family - has experienced protest movements. There was a wave of dissatisfaction on the Russian political scene in 2011 and 2012. Urban demonstrations were a classical instance of the electoral protests common in regimes of "electoral authoritarianism". Many journalists and political commentators compared it to the wave of protests in Tunisia, Egypt, and Libya in 2010-2013 (especially as the Russian protesters also used social networks like Facebook and Vkontakte).

In BRICS and other developing countries, inequality, accompanied by such factors as weak markets, governments and institutions, is a serious setback for growth and an invitation to political instability. However, reducing inequality does not mean an "automatic transmission" to high growth, or efficient government with cohesive social institutions. This stems from the fact that inequality is multidimensional, it bears not only an "income face" but also restricts access to basic services, infrastructure, knowledge, innovation, affects spatial disparities and various consumption patterns. In the case of such BRICS members as India, Brazil or South Africa, inequality factors are additionally influenced by strong dependency, as these countries inherited extremely backward economies with asymmetric social and economic structures from the colonial rulers. The example of India shows that the majority of its population, especially rural residents (about 70 per cent of population), the uneducated and poor, are incapable of coping with market problems, and thus have been excluded from access to opportunities for economic advancement, created by a surge of Indian ambitions to play an important role in the world economy (Nakonieczna, 2014). The deepening mismatch between "the haves" and "the have-nots" translates into unbalanced consumption of the fruits of globalization. Arundhati Roy (2005) writes: "India lives in several centuries at the same time, making progress and simultaneously losing ground". The rift between the fabulously rich, supported by corrupt local authorities and foreign investors, and the extremely poor, exploited in the labour market, deprived of basic civil rights and discouraged from active civic and social life, may be a stumbling block for those political parties which promote economic development at the cost of rising inequalities. This fate has 
befallen the Indian Bharatiya Party (BJP), which lost power in the parliamentary elections in 2004 (Nakonieczna, 2014).

Multidimensional inequality in BRICS may refer to opportunities (access to land, health, knowledge, financial means) and outcomes (income, wages, the intersectoral differential between wages and productivity, and, finally, patterns of employment - formal and informal). Francesca Beausang notes that: " $\mathrm{t}$ ]wo individuals with the same opportunity may end up with different incomes, based on who is the more ambitious or hard-working; that seems like a fair outcome. More problematic is the situation where two individuals, with the same ambition and work ethic, end up with different incomes because they did not have the same opportunity" (Beausang, 2012). The next subsection of this article will look into both opportunity and outcome inequalities in BRICS.

\section{ENTERING THE DORMANT DRAGON'S DEN: BRICS AND THE THREAT OF INEQUALITY}

According to OECD estimates, BRICS, in particular South Africa and Brazil, are among the most unequal societies in the world. The estimates show that the group members' income inequality in the late $2000^{\text {s }}$ has risen compared to the early 1990s, apart from Brazil (Fig.1).

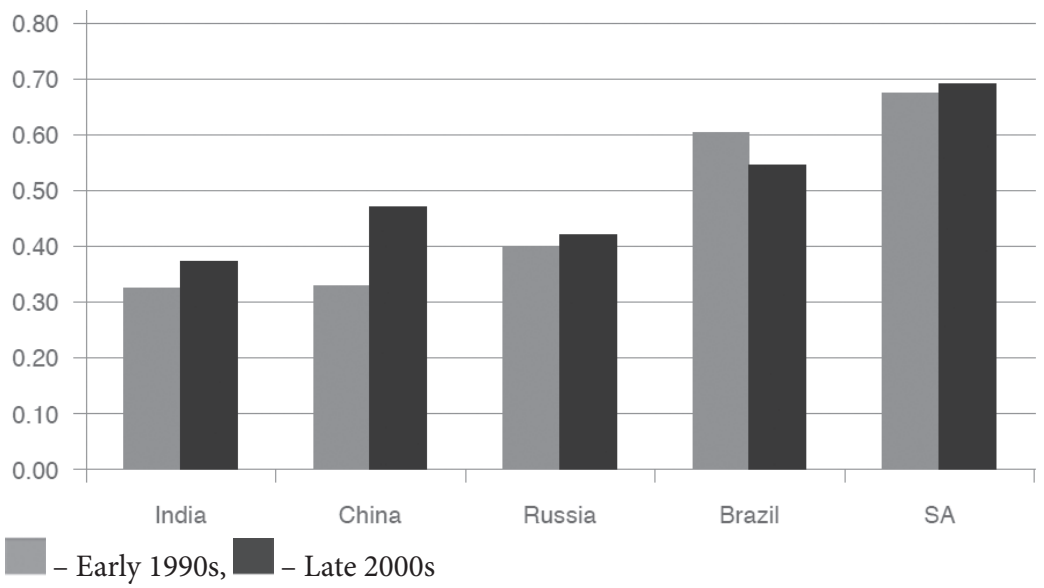

Figure 1. Income inequality in BRICS countries measured with GINI coefficient Source: Divided We Stand: Why Inequality Keeps Rising, Paris: OECD 2011. 
The World Bank roughly confirms these estimates. According to the World Development Index (WDI, 2016), the GINI coefficient in the BRICS countries is as follows: Brazil - 52.9 (2013); Russia - 41.6 (2012); India - 33.9 (2009); China - 42.1 (2010); South Africa - 63.4 (2011). The OECD and World Bank's estimates differ with reference to China, which appears to be well above the 0.4 level that is usually considered a critical threshold for political unrest. According to inequality data published by the Chinese National Bureau of Statistics in 2013 (first release since 2000), China's Gini peaked at 0.49 in 2008 before falling to 0.47 in 2012 (The Telegraph, 2016). However, these figures may be downgraded, as shown in a study of approx. 8,500 households carried out by the Survey and Research Center for China Household Finance, a body set up by the Finance Research Institute of the People's Bank of China and Southwestern University of Finance and Economics, which found that the Gini coefficient in China was 0.61 in 2010, with 10 per cent of households capturing up to 57 per cent of the country's disposable income (Caixin, 2012). The survey also estimated the urban jobless rate in July 2012 was 8.05 per cent, almost double the official figure. Additionally, the Chinese Academy of Social Sciences, a state research institute, estimated inequality at 0.54 in 2008 (Bloomberg, 2012).

The huge income disparities in BRICS (GINI > 0.40), combined with high food and house prices, not only fuel opportunity inequalities and growing social anger, but also lead to political instability and setbacks on the path to balanced growth. High food prices and expenditures have played a part in fostering civil unrest in Egypt and other Arab countries, and raised concerns about a possible food crisis in developing countries, as world food prices reached their highest levels in January 2011 (a typical Egyptian family spent about 40 per cent of monthly income on food in 2011). Food price inflation, poverty and lack of opportunities, as exemplified by the tragic self-immolation of Mohamed Bouazizi, a young fruit vendor, in December 2010, led to a series of unprecedented demonstrations in Tunisia, which soon spread to other Middle East and North Africa (MENA) countries. A mounting wave of unrest engulfed Algeria, Jordan, Egypt, and Yemen. The Arab streets, full of desperate individuals who lived under the same very difficult conditions, shared Bouazizi's experience of unemployment, but also found an opportunity to express their frustration and dissatisfaction with a corrupt system that was seen as a "law enforcement facility" against the poorest, and for the increasingly flagrant theft of land and resources by the elite. As the share of household spending devoted to food purchases increases, food prices have a greater impact on living standards, poverty rates, 
economic development and domestic politics. According to Credit Suisse's Emerging Consumer Survey (Credit Suisse, 2015), consumers' food purchases in China and India in 2014 were at roughly 16 per cent and 21 per cent of total monthly spending, respectively. Consumers in South Africa, Brazil and Russia spent about 16 per cent, 17 per cent and 34 per cent of income, respectively. Given that food items are fundamental in consumption patterns, for consumers in Russia and India household expenditures on food purchases became quite a challenge because of food inflation, which weakens households' purchasing power. It suffices to indicate that in November 2015, the country with the highest monthly food inflation in BRICS was Russia (17.7 per cent), followed by Brazil (11.6 per cent), and India (6 per cent) (The Economist, 2016). Food inflation has been one of the harshest consequences for ordinary Russians, mostly due to the country's confrontation with the West over Ukraine and the ongoing economic crisis. The steep devaluation of the rouble and bans on imports of European produce due to Moscow's retaliation to the sanctions pushed the average cost of food up by 20 per cent in the 12 months between July 2014 and 2015 (Bazenkova, 2016). Average prices in some categories increased even more. The cost of vegetables and fruit over the given time increased approx. 23 per cent, sugar increased by 29.6 per cent, fish and seafood by 31.4 per cent, grains and legumes by 43.4 per cent. In a society where 94 per cent of the adult population, estimated at 143 million, owns less than $\$ 10,000$, such food inflation undoubtedly has a negative impact on social capital, trust and contributes to public dissatisfaction and instability. Examples of civil unrest may be easily found amongst BRICS members. Among the most memorable were the protests which India experienced in 2011 inspired by Anna Hazare, India's most prominent anti-corruption campaigner, fighting corruption scandals and rampant food inflation. In addition to the above-mentioned, social unrest, which gathered a crowd of 100,000 in Moscow in December 2011, as well as protests, riots and demonstrations in China, which doubled from 2006, rising to at least 180,000 cases in 2010, forced governments to talk about the "softening" of economic policy in order to avoid open rebellion instigated by public anger over high food prices, unemployment and the unrestrained power of officials. For instance, in February 2013, China's State Council approved a 35-point income-distribution plan intended to tackle the nation's wealth gap, addressing such issues as raising minimum wages to at least 40 per cent of average salaries, loosening controls on lending and deposit rates, and increasing spending on education and affordable housing (Bloomberg, 2013). The deficit in the provision of adequate housing and 
amenities is even more evident in India, where the shortfall of proper shelter places one-fourth (93 million) of the Indian urban population, estimated in the 2011 national census at approx. 377 million people (Census..., 2011), below the poverty line. Additionally, in Indian cities in 2011, approximately 20 million inhabitants were living in 49,000 slums. Housing inequality in India also has a "socio-religious face". This applies to communities like the Dalits (16.5 per cent of the population; IDSN, 2013), which are at the bottom of the Hindu caste system and the largest minority - Muslims (14 per cent of the population), also vulnerable to poverty. According to the Housing Condition and Amenities in India 2008-09 report (Government..., 2010), Hindus have more housing space (41 square metres) than Muslims (37.8) and Dalits (34.7). Additionally, Muslims and Dalits are disadvantaged in their access to (separate) kitchens, private latrines, bathrooms and drinking water facilities. Since 1950, the Indian government has been trying to use the world's oldest affirmative action programme, including quotas targeted at the Dalits, classified as the "Scheduled Caste", Adivasi, the 8 per cent of India's population, labelled as "Scheduled Tribes" and so-called "Other Backward Classes", a diverse group of lower classes that represent about 27 per cent of the country's population. The Indian system of reservations, which is a type of affirmative action whereby a proportion of seats is set aside for the disadvantaged in the Parliament of India, state legislative assemblies, central and state civil services, public sector units, central and state government departments and all public and private educational institutions (Tummala, 1999) in some respects has succeeded. In 1965, Dalits held less than 1.6 per cent of senior civil service positions. That rose to 11.5 per cent by 2011 . However, in other areas the progress (if any) was meagre. Very few Indians have formal jobs, let alone government ones. Ineffective job policies contributed to increasing Indian red tape, making it difficult to dismiss dysfunctional or corrupt bureaucrats. In education, where quotas and scholarships were introduced in 1920, more Dalit and tribal children were encouraged to attend schools at primary and secondary levels, but at the same time, setting aside special places in colleges and universities for Dalit and other backward applicants, resulted in lowering demands from them as applicants, which caused widespread resentment among young people competing for the opportunity to enter a professional career. According to Pratap Bhanu Mehta, an academic at the Centre for Policy Research in Delhi, the affirmative action, despite its light side, also has a dark side, which stems from its structural weakness. As he aptly notes, "[t]he current system is not about equal opportunity, it is about distributing the spoils of state power strictly 
according to caste, thus perpetuating it" (The Economist, 2013b). This gloomy notion about the inevitability of the failure of a policy focused on the distribution of limited state resources may be up to date. Even Brazil, which provided more equal access to education for the workforce in the mid-1990s, and initiated income transfer programmes directed towards reducing extreme poverty, reached a standstill if not a reverse. The incomes of the Brazilian bottom 5 per cent in the mid-2000s declined by 14 per cent. Inequality reduction policies lifted the poorest out of poverty in rural areas, while neglecting the poor in numerous cities and those who are not "the poorest of the poor" (Beausang, 2012). In other words, the Brazilian government, having limited resources, has chosen to help those in dire need without taking care of the others, and thus silently agreed to perpetuate structural mechanisms of inequality. As F. Beausang aptly notes: "Brazilian inequality is deeply rooted in the structural mechanisms that perpetuate it, the most entrenched of which are the coalitions between social classes, particularly landowners and business, which oppose urban wage workers and the rural masses. Since colonization, these coalitions have prevailed in the concentration of land and political power. They have blocked attempts to change the distribution of income or provide social services for the poor" (ibid.). Hence the persistence of inequality, regardless of changing political regimes and development strategies.

\section{CONCLUSION}

BRICS members, since the financial crisis broke out in 2008, have experienced massive riots, protests, acts of civil disobedience rooted in increasing income and wealth inequality, poor opportunities to gain decent education, health services, access to housing and amenities, ethnicity, colour and gender disparities, and, finally, strong territorial inequality (urban-rural divide) in social and economic terms. Inequality and poverty, inevitably linked to the historical dependency of Brazil's and South Africa's political economies, continue to constitute a worrying reality, notwithstanding recent improvements in the case of Brazil. Increasing inequality in both China and India where "the Gini has overtaken the growth rates" (Couto Soares, Scerri, Maharajh, 2014) poses a serious threat to political stability. Finally, Russia, with a record low rate of social capital and incredibly high concentration of national wealth in the hands of 110 billionaires, jealously guarding 35 per cent of the nation's wealth, draw a rather gloomy picture of the 
emerging powers, where high levels of inequality, like "bad cholesterol", have combined with rising inflation (in particular food and housing), large fiscal deficits and public debt, stifling growth and showing the structural weaknesses of economies once hailed as star performers in the emerging world. Apparently, describing BRICS members as "giants with feet of clay" would be more appropriate. With weak markets, weak governments and weak institutions, they are unable to calm the social unrest which, as Bandura (1977) notes, occurs when individuals consider themselves highly capable but perceive that they have little control over the social or political processes in their country. The example of the recent powerful protests which began in Brazil in June 2013, where the protesters initially demanded lower-cost public transportation, but eventually expressed their dissatisfaction with the quality of government services, shows that individuals can "engage in protest or outright rebellion when they see problems in their society or with their position in society and at the same time believe they can effect change only by protesting the established system" (Flechtner, 2014).

There is, however, a question of why, despite the GINI coefficient in BRICS being significantly higher than those of Egypt and Tunisia in 2010-2011, the recent bursts of public dissatisfaction have not swept away the ruling elites in Brazil, Russia, India, China, and South Africa?

Firstly, the answer may be the partly hidden socio-historical differences between the emerging powers and the MENA world. The Arab uprising in Egypt and Syria, the war against Qaddafi and public unrest in Tunisia, which had a much more devastating impact on political stability than the "soft" protests and riots in BRICS, have a long history rooted in the acts of disobedience in Muslim societies after Muhammad's revelations. Even in the $8^{\text {th }}$ and $9^{\text {th }}$ centuries, there was a strong connection between the ruler and the urban population or, in other words, the palace and the market. According to Albert Hourani, in medieval Arab societies sometimes the alliance of interests or a certain balance of power between the ruler and those he relied on, could be shaken. The discontent of the possessing classes in the city did not usually take the form of open disobedience, because certain privileged groups had too much to lose. However, among the ordinary people, the discontent could take the form of disturbance of the order. As Hourani puts it: " $[t]$ he skilled craftsmen and shopkeepers would not easily revolt except under pressure of hardship, the oppression of officials, high process, shortage of food or materials; their normal condition was one of acquiescence, since their interest lay in the preservation of order. The proletariat, however, the mass of rural immigrants, unskilled casual workers, beggars and habitual 
criminals on the outskirts of the city, was in a more permanent state of unrest" (Hourani, 2005).

Secondly, the more violent turn of the political unrest in Egypt and Tunisia in comparison to BRICS can be explained by the correlation between the rising aspirations of the young population, acquired thanks to a relatively large number of them obtaining a higher education diploma and high unemployment. Tunisia and Egypt in 2010 had a relatively high percentage of the population aged 18 to 24 enrolled in higher education (more than 30 per cent; WDI, 2013) while in Brazil it was 14.4 per cent. Access varied across regions. In the south of Brazil, 19.2 per cent of young people in the age group attended higher education in 2010, while in the northeast the index was below 10 per cent (IPEADATA, 2011). The higher education rate in Tunisia, Egypt and other MENA countries was mixed with very high unemployment among college graduates (far exceeding that in BRICS), which in the MENA region is higher than that prevalent among uneducated and illiterate Arabs.

Thirdly, the lower intensity of protest against injustice and inequality in BRICS countries in comparison to MENA may be explained by the "tunnel effect", introduced by economists Hirschman and Rothschild (1973) and further developed by Debraj Ray (2010). In Hirschman and Rothschild's model, perceptions of inequality in a developing society are compared to car drivers stuck in a traffic jam and waiting in a lane. As long as the neighbouring lane was moving they felt relieved, believing their turn was next. In the case of BRICS, with record-high inequalities, societies are willing to accept disparities when they think that in the course of time they will benefit (the lane will start moving). However, if only one lane moves (a certain group pick up benefits) and the rest stand still (cut from benefits), the sentiment of anger takes over and contributes to a rising tide of political instability. According to Ray, economic growth combined with increased inequality would stimulate aspirations on condition that people who are not benefiting from the growth could expect to benefit soon. In India, where affirmative action brought moderate success, or in Brazil, where Bolsa Familia and other income transfer programmes gave hope to "the poorest of the poor", a part of society still prefers to wait and see, or "wait in a lane" believing that growth will be used to fulfil the aspirations of all levels of society. However, with the limited resources which BRICS (except from China) have at their disposal, and the de facto "bad inequality" which spreads faster than growth, help will likely be reserved to those in dire need, while neglecting vast groups of society that may contribute to long-term development. 


\section{ReFERENCES:}

Alesina, A., Rodrik, D. (1994). Distributive Politics and Economic Growth. Quarterly Journal of Economics, 109(2), 465-490.

Alesina, A., Perotti, R. (1996). Income Distribution, Political Instability, and Investment. European Economic Review, 40, 1203-1228.

Atkinson, A., Piketty, T., Saez, E. (2011). Top Incomes in the Long Run of History. Journal of Economic Literature, 49(1), 3-71.

Barro, R., Sala-i-Martin, X. (1995). Economic Growth. New York: McGraw Hill.

Beausang, F. (2012). Globalization and the BRICs. Why the BRICs Will Not Rule the World for Long. New York: Palgrave Macmillan.

Bertola, G. (1993). Market Structure and Income Distribution in Endogenous Growth Models. American Economic Review, 83, 1184-1199.

Bandura, A. (1977). Social Learning Theory. Englewood Cliffs, N.J.: Prentice Hall.

Baumol, W. (1990). Entrepreneurship: Productive, Unproductive and Destructive. Journal of Political Economy, 98(5), Part 1, 893-921.

Bazenkova, A. (2016). Russian Food Prices Stabilize After Months of Racing Inflation. Retrieved from: http://www.themoscowtimes.com/business/article/russian-foodprices-stabilize-after-months-of-racing-inflation/526610.html.

Birdsall, N. (2007). Inequality Matters. Retrieved from: http://bostonreview.net/nancybirdsall-inequality-matters.

Bloomberg. (2012). China Survey Shows Wealth Gap Soaring as Xi Pledges Help. Retrieved from: http://www.bloomberg.com/news/2012-12-09/china-s-wealthgap-soars-as-xi-pledges-to-narrow-income-divide.html.

Bloomberg. (2013). China Approves Income Plan as Wealth Divide Poses Risks. Retrieved from: http://www.bloomberg.com/news/articles/2013-02-05/china-approvesincome-plan-as-wealth-divide-poses-risks.

Caixin. (2012). China's Gini Index at 0.61. Retrieved from: http://english.caixin. com/2012-12-10/100470648.html.

Census of India. (2011). Retrieved from: http://www.censusindia.gov.in/2011-provresults/paper2/data_files/india/paper2_at_a_glance.pdf.

Couto Soares, M.C., Scerri, M., Maharajh, R. (2014). The Co-evolution of Innovation and Inequality. In: M.C. Couto Soares, M. Scerri, R. Maharajh (eds.), Inequality and Development Challenges (p. 1-18). Abingdon: Routledge.

Couto Soares, M.C., Podcameni, M.G. (2014). Inequality, Innovation System and Development: The Brazilian Experience. In: M.C. Couto Soares, M. Scerri, R. Maharajh (eds.), Inequality and Development Challenges (p. 19-79). Abingdon: Routledge.

Credit Suisse. (2015). Emerging Consumer Survey. Retrieved from: https://www.creditsuisse.com/media/am/docs/asset-management/emerging-consumer-survey 2015. pdf? source=text.

Facchini, F. (2008). Inequalities and Growth: Are There Good and Bad Inequalities?. Université Paris1 Panthéon-Sorbonne Working Paper, No hal-00270483. 
Flechtner, S. (2014). Aspiration Traps: When Poverty Stifles Hope. Inequality in Focus, 2(4).

Garcia-Herrero, A. (2015). Brazil: Playing with Fire. Retrieved from: http://bruegel. org/2015/11/brazil-playing-with-fire/.

Global Wealth Report. (2013). Credit Suisse Bank. Retrieved from: https://publications.credit-suisse.com/tasks/render/file/?fileID=BCDB1364-A105-0560 -1332EC9100FF5C83.

Government of India. (2010). Housing Condition and Amenities in India 2008-09. National Sample Survey Office Ministry of Statistics \& Programme Implementation. Held, D. (2010). Cosmopolitanism: Ideals, Realities and Deficiencies. Cambridge: Polity. Hirschman, A.O., Rothschild, M. (1973). The Changing Tolerance for Income Inequality in the Course of Economic Development; with a Mathematical Appendix. Quarterly Journal of Economics, 87(4), 544-566.

Hourani, A. (2005). A History of the Arab Peoples. Croydon: CPI Bookmarque.

Li, Hongyi; Zou, Heng-fu (1998). Income Inequality Is Not Harmful for Growth: Theory and Evidence. Review of Development Economics, 2(3), 318-334. DOI: 10.1111/1467-9361.00045.

IDSN. (2013). India: Official Dalit Population Exceeds 200 Million. Retrieved from: http://idsn.org/india-official-dalit-population-exceeds-200-million.

IPEADATA. (2011). Educação IPEADATA Database 2011. Retrieved from: http://www. ipeadata.gov.br.

Kaldor, N. (1960). Essays on Value and Distribution. Free Press, Glencoe, Ill.

Kalecki, M. (1971). Selected Essays on the Dynamics of the Capitalist Economy 1933-1970. Cambridge: Cambridge University Press.

Kawachi, I., Kennedy, B.P., Lochner, K., Prothrow-Stith, D. (1997). Social Capital, Income Inequality, and Mortality. American Journal of Public Health, 87(9), $1491-1498$

Kuznets, S. (1955). Economic Growth and Income Inequality. The American Economic Review, 45(1), 12-18.

Luebker, M. (2010). Inequality, Income Shares and Poverty: The Practical Meaning of Gini Coefficients. Geneva: International Labour Office.

Lukov, V. (2012). A Global Forum for the New Generation: The Role of the BRICS and the Prospects for the Future. Retrieved from: http://www.brics.utoronto.ca/analysis/ Lukov-Global-Forum.html.

MercoPress. (2011). Brazilian Has 190.7 Million Population, and 14.6 Million Illiterates. Retrieved from: http://en.mercopress.com/2011/04/30/brazilian-has-190.7-millionpopulation-and-14.6-million-illiterates.

Mihăilescu, I. (1974). Sociologie generală: concepte fundamentale şi studii de caz. Editura Polirom, Iași.

Milanovic, B. (2010). The Haves and the Have-Nots. New York: Basic Books.

Nakonieczna, J. (2014). Alter-globalisation in India. In: J. Zajączkowski, M. Thapa, J. Schöttli (eds.), India in the Contemporary World. Polity, Economy and International Relations (p. 158-176). London: Routledge. 
Perotti, R. (1993). Political Equilibrium, Income Distribution, and Growth. The Review of Economic Studies, 60(4), 755-776.

Persson, T., Tabellini, G. (1994). Is Inequality Harmful for Growth? Theory and Evidence. American Economic Review, 84, 600-621.

Piketty, T., Saez, E. (2003). Income Inequality in the United States, 1913-1998. The Quarterly Journal of Economics, 118(1), 1-39.

Piketty, T. (2014). Capital in the Twenty-First Century. Cambridge: The Belknap Press of Harvard University Press.

Ray, D. (2010). Uneven Growth: A Framework for Research in Development Economics. Journal of Economic Perspectives, 24(3), 45-60. DOI: 10.1257/jep.24.3.45.

Rodríguez, F. (2000). Inequality, Economic Growth and Economic Performance. Washington: The World Bank.

Rogoff, K. (2011). A imprevisibilidade da desigualdade. Retrieved from:

http://www.jornaldenegocios.pt/opiniao/detalhe/a_imprevisibilidade_da_desigualdade.html.

Roy, A. (2005). Panie mają przeczucia więc... In: A. Roy (ed.), Algebra bezgranicznej sprawiedliwości. Poznań: Zysk i S-ka.

Shlapentokh, V. (2006). Trust in Public Institutions in Russia: The Lowest in the World. Communist and Post-Communist Studies, 39(2), 153-174. DOI: 10.1016/j. postcomstud.2006.03.004.

Stunkel, O. (2015). The BRICS and the Future of Global Order. London: Lexington Books.

The Economist. (2013a). Infrastructure: The Road to Hell. Retrieved from: http://www. economist.com/news/special-report/21586680-getting-brazil-moving-again-willneed-lots-private-investment-and-know-how-road.

The Economist. (2013b). Affirmative Action. Indian Reservations. BBC, 29 June, 2013. Retrieved from: http://www.economist.com/blogs/banyan/2013/06/affirmativeaction.

The Economist. (2016). Countries With Highest Food Inflation - Top 11 BRICS. Retrieved from: http://ieconomics.com/top-11-food-inflation-brics.

The Telegraph. (2016). China Breaks Long Silence on Inequality Statistic. Retrieved from: http://www.telegraph.co.uk/finance/economics/9810436/China-breaks-longsilence-on-inequality-statistic.html.

Tummala, K. (1999). Policy of Preference: Lessons from India, the United States, and South

Africa. Public Administration Review, 59(6), 495-508. DOI: 10.2307/3110298.

WDI. (2013). World Development Indicators: Education Gaps by Income, Gender and Area. Retrieved from: http://wdi.worldbank.org/table/2.11.

WDI. (2016). World Development Indicators Database. The World Bank. Retrieved from: http://data.worldbank.org/indicator/SI.POV.GINI.

Wilson, W.J. (1991). Studying Inner-City Social Dislocations: The Challenge of Public Agenda Research. American Sociological Review, 56(1), 1-14. 